\title{
ÁL-FÂHIM
}

\section{Jurnal Manajemen Pendidikan Islam}

Manajemen Strategi Pemasaran Pendidikan

Di SDIT Alam Nurul Islam Sleman

Jamaludin

Menakar Kebijakan Pendidikan Nasional Dan Pendidikan Islam Di Indonesia Era Reformasi (Presiden Habibie Sampai Presiden Jokowi Jilid I) Permana Octofrezi

Peran Kepala Sekolah Dalam Implementasi Manajemen Mutu

Peserta Didik (Smk Darul Maghfiroh Di Sinar Rejeki, Kecamatan Jati Agung, Kabupaten Lampung Selatan) Andrianto

Konsep Ulul Albab Dalam Manajemen Kepemimpinan Pendidikan Islam Nimas Wegig Kurniana

Analisis Kritis Kepemimpinan Pendidikan Islam Berdasarkan Syarat Dan Ciri-Ciri Kepemimpinan Yang Ideal Siti Qurrotul A'yuni, Radia Hijrawan

Menjadi Pemimpin Yang Efektif Dan Berpengaruh

Di Madrasah Munganatul Khoeriyah

Upaya Sekolah Dalam Meningkatkan Prestasi Non Akademik Siswa Melalui Manajemen Sarana Prasarana Di SMP Muhammadiyah Boarding School Pleret Safinatun Munawaroh, Rz. Ricky Satria Wiranata

Diterbitkan Oleh:

Prodi Manajemen Pendidikan Islam STAIT Yogyakarta 


\section{$\frac{\text { ÁL-FÂHIM }}{\text { Jurnal Manajemen Pendidikan stam }}$}




\section{ÁL-FÂHIM \\ Jurnal Manajemen Pendidikan Islam}

$\begin{array}{ll}\text { Penangung Jawab } & \text { : Danang Dwi Prasetyo } \\ \text { Ketua Redaksi } & \text { : Rz. Ricky Satria Wiranata } \\ \text { Editor } & \text { : Denas Hasman Nugraha } \\ \text { Reviewer } & \text { : Syarif Hidayat } \\ & \text { Suprih Hidayat } \\ \text { Tata Usaha } & \text { Sulis Ariawan } \\ & \text { Nita Kumalasari } \\ \text { Penerbit } & \text { Sekolah Tinggi Agama Islam Terpadu } \\ & \text { Yogyakarta } \\ \text { Alamat Redaksi } & \text { : Jl. Mendung warih No. 125 Giwangan, } \\ & \text { Umbulharjo, Yogyakarta } \\ & \text { Telp. (0274) 410350, 4281163 } \\ & : \text { redaksialfahim@gmail.com } \\ \text { Email } & \text { : jurnal.staitbiasjogja.ac.id } \\ \text { Website } & \end{array}$

\section{Deskripsi:}

ÁL-FÂHIM adalah jurnal Manajemen Pendidikan Islam yang diterbitkan secara berkala selama enam bulan sekali oleh Prodi Manajemen Pendidikan Islam Sekolah Tinggi Agama Islam Terpadu Yogyakarta berdasarkan Keputusan Ketua STAIT Jogja Nomor 001/A.KEP/STAITJOGJA/II/2019 tanggal 18 Februari 2019. Jurnal ÁL-FÂHIM adalah sarana kaum intelektual sebagai media informasi dan penyebarluasan hasil studi penelitian dan artikel ilmiah dibidang Manajemen Pendidikan Islam.

Jurnal ÁL-FÂHIM mengundang para Dosen, Pendidik dan praktisi Pendidikan Islam untuk menyumbangkan karya ilmiahnya di bidang Manajemen Pendidikan Islam. Naskah yang dikirim akan diseleksi dan dipublikasikan sesuai aturan dan ketentuan yang berlaku. Karya Ilmiah yang dimuat di Jurnal ÁLFÂHIM tidak selamanya mencerminkan pendapat redaksi. 
DAFTAR ISI

Vol. 02 No. 02 September 2020

Halaman Judul .................................................................................. $\mathrm{i}$

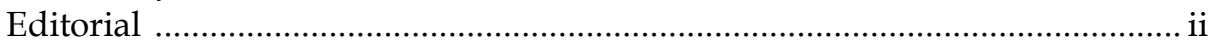

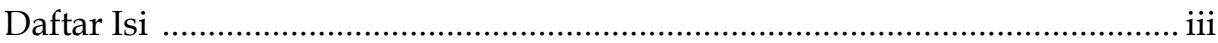

Manajemen Strategi Pemasaran Pendidikan Di SDIT Alam Nurul Islam Sleman

Jamaludin

Menakar Kebijakan Pendidikan Nasional Dan Pendidikan Islam Di

Indonesia Era Reformasi (Presiden Habibie Sampai Presiden Jokowi Jilid I)

Permana Octofrezi

Peran Kepala Sekolah Dalam Implementasi Manajemen Mutu Peserta Didik (SMK Darul Maghfiroh Di Sinar Rejeki, Kecamatan Jati Agung, Kabupaten Lampung Selatan)

Andrianto

Konsep Ulul Albab Dalam Manajemen Kepemimpinan Pendidikan Islam

Nimas Wegig Kurniana

Analisis Kritis Kepemimpinan Pendidikan Islam Berdasarkan Syarat Dan Ciri-Ciri Kepemimpinan Yang Ideal

Siti Qurrotul A'yuni, Radia Hijrawan ........................................................................ 68

Menjadi Pemimpin Yang Efektif dan Berpengaruh di Madrasah

Munganatul Khoeriyah

Upaya Sekolah Dalam Meningkatkan Prestasi Non Akademik Siswa Melalui Manajemen Sarana Prasarana Di SMP Muhammadiyah Boarding School Pleret

Safinatun Munawaroh, Rz. Ricky Satria Wiranata 


\title{
Peran Kepala Sekolah Dalam Implementasi Manajemen Mutu Peserta Didik (Smk Darul Maghfiroh Di Sinar Rejeki, Kecamatan Jati Agung, Kabupaten Lampung Selatan) \\ Andrianto \\ UIN Sunan Kalijaga Yogyakarta andriantoanto949@gmail.com
}

\begin{abstract}
The role of the principal in implementing the quality management of learners is the activity of the principal responsible for the implementation of education, the school principal must be able to manage the management process from the planning, implementation, and to the evaluation stage of the outcome of learning, to achieve the success of the organization or institutions in achieving objectives and various objectives and ability to face various challenges, both external and, practices in the field, this can affect the performance of teachers in carrying out their duties in teaching and learners who receive the lesson, so that it can achieve the quality of education. The type of research used is field research, i.e. research that includes the facts and problems that exist in the field, with the method of research used is the descriptive qualitative research in SMK Darul Maghfiroh SInar Rejeki, District Jati Agung, Kabupaten Lampung Selatan, with the technique of collecting data in this research include: observation, interviews, documentation, while the validity test of data is done with the triangulation technique, during the research is analysts, data presentation, and withdrawal of conclusions. The role of the principal in the implementation of quality management by carrying out its duties precisely is planning, organizing activities, directing activities, implementing supervision, and implementing management management and organizing the school relationship with the community and other Instasi. The principal is the control holder in his school so that in organizing and implementing it all the headmaster can not do it alone, the principal should be able to invite and give a positive influence so that teachers and students can cooperate wholeheartedly, with such a purpose the school will be easier to achieve.
\end{abstract}

Key words: The Role of School Principals, Student Quality.

\section{Pendahuluan}

Pendidikan merupakan investasi yang paling utama bagi bangsa, apalagi bangsa yang sedang berkembang. Pembangunan hanya dapat dilakukan oleh manusia yang untuk itu di persiapkan melalui pendidikan. ${ }^{4}$ Maju mundurnya suatu bangsa tidak terlepas dari maju mundurnya dunia pendidikan. Pendidikan merupakan sarana penunjang pembangunan bangsa. Pendidikan diharapkan mampu mencetak manusia yang berkualitas

48Nasution, Teknologi Pendidikan, (Jakarta, Bumi Aksara, 1990), hal.2. 
serta mempunyai kemampuan dalam menjalankan dan memajukan pembangunan bangsa. ${ }^{49}$

Pendidikan merupakan bagian penting dari proses pembangunan nasional dan investasi dalam pengembangan sumber daya manusia. Pendidikan yang baik diharapkan dapat meningkatkan kecakapan dan kemampuan yang diyakini dapat mendukung upaya manusia dalam mangarungi kehidupan yang penuh dengan ketidakpastian. Sekolah sebagai salah satu wahana pendidikan diharapkan dapat menghasilkan sumberdaya manusia yang cakap dan mampu menaungi kehidupan di masa depan. Pengelolaan sekolah yang baik akan dapat menghasilkan sumber daya manusia seperti yang diharapkan.

Pada saat ini diperlukan adanya dukungan manajemen yang efektif dan efesien dalam organisasi pendidikan, karena semakin besarnya perhatian dan pengakuan dari berbagai pihak. Peserta didik perlu dibangun mentalitasnya sehingga mampu berpikir kreatif dan mampu mengembangkan minat serta bakatnya untuk mampu bersaing didunia kerja dan bisa bekerja secara professional dan berdedikasi yang tinggi terhadap profesinya. Manajemen merupakan proses pendayagunaan semua sumber daya dalam rangka mencapai sebuah tujuan yang ditetapkan. Pendayagunaan yang melalui proses perencanaan, pengorganisasian, pengarahan, dan pengawasan disebut manajemen. ${ }^{50}$

Lembaga pendidikan akan lebih efektif dalam memberikan pendidikan yang baik pada peserta didiknya apabila lembaga pendidikan dikelola dengan baik. Dan hal ini membuktikan bahwa mutu manajemen dan kepemimpinan merupakan salah satu fariabel terpenting untuk membedakan sekolah yang berhasil. Sekolah harus mampu menampung aspirasi masyarakat dan dunia kerja untuk dapat diterima dan diminati oleh konsumen pendidikan. Sehingga sekolah benar- benar menerapkan manajemen yang efektif untuk menyelenggarakan pendidikan yang bermutu dan dapat dirasakan oleh konsumen pendidikan tersebut. Untuk menciptakan pendidikan yang berkualitas harus ada pelayanan yang terus menerus yang senantiasa menjaga standar mutunya dan tentunya adanya kerjasama pihak internal dan eksternal sekolah yang terus-menerus dibina dan dilakukan secara baik serta terencana.

Sekolah sebagai institusi pendidikan yang merupakan wadah tempat proses pendidikan dilakukan, memiliki sistem yang kompleks dan dinamis. Dalam kegiatan sekolah bukan hanya sekedar tempat berkumpul guru dan murid, tetapi sekolah berada dalam satu tatanan sistem yang rumit dan

${ }^{49}$ Amirudin, Kepemimpinan Kepala Madrasah Dalam Meningkatkan Kedisiplinan Guru, Fakultas Tarbiyah dan Keguruan UIN Raden Intan Lampung , Al-Idarah: Jurnal Kependidikan Islam Vol. 7 No. 2, Desember 2017, hal 24.

50Ibrahim Bafadal, Manajemen Perlengkapan Sekolah dan Aplikasinya, (Jakarta, PT Bumi Aksara, 2004), hal. 1. 
saling berkaitan. Oleh karena itu sekolah dipandang sebagai suatu organisasi yang membutuhkan pengelolaan. Kegiatan sekolah ini adalah pengelolaan sumber daya manusia yang diharapkan menghasilkan lulusan yang berkualitas tinggi dengan tuntutan kebutuhan masyarakat bangsa perlu dikelola, diatur, dicatat dan diberdayakan agar dapat menghasilkan produk atau hasil secara optimal. ${ }^{51}$

Dalam peningkatan mutu peserta didik tentunya tidak akan terlepas dari konsep pelayanan total dalam manajemen atau yang dikenal dengan Total Quality Management (TQM). Defnisi TQM yang diberikan oleh Mars J. (1992) sangat membantu dalam penekanan pada aspek-aspek yang menonjol dalam pendidikan: Mutu terpadu adalah sebuah filosof dengan alat-alat dan proses-proses implementasi praktis yang ditujukan untuk mencapai sebuah kultur perbaikan terus-menerus yang digerakkan oleh semua pekerja sebuah organisasi, dalam rangka memuaskan pelanggan. ${ }^{52}$

Di Indonesia pendekatan manajemen berbasis sekolah disamping diposisikan sebagai kritik atas penyelengaraan pendidikan yang selama ini tersentralisasi. Pendidikan sentralisasi tidak mendidik manajemen sekolah untuk belajar mandiri, baik dalam hal manajemen kepemimpinan maupun dalam pengembangan institusional, pengembangan kurikulum, penyediaan sumber belajar, alokasi sumber daya dan terutama membangun partisipasi masyarakat untuk memiliki sekolah. Peningkatan pengaruh sekolah, perlu dukungan para stakeholder yang meliputi pemerintah daerah, komite sekolah (kepala sekolah, guru, orang tua siswa, dan tokoh masyarakat, serta peserta didik). Pengambilan keputusan bersama di kalangan stakeholders pada level sekolah merupakan kunci utama dalam melaksanakan manajemen berbasis sekolah. ${ }^{33}$

Secara sederhana Manajemen mempunyai arti yang sangat luas dan bisa masuk dalam ranah ilmu lainnya. Lebih dikenal bahwa manajemen sering digunakan dalam suatu lembaga atau organisasi yang telah ada. Melihat dari sini bahwa pendidikan yang berada dalam suatu lembaga tentunya tidak bisa lepas dari manajemen atau pengelolaan untuk mengembangkan tercapainya tujuan pendidikan. ${ }^{54}$ Berbicara tentang manajemen, dewasa ini banyak yang menafsirkan istilah manajemen dengan berbagai pengertian gaya bahasa masing-masing. Maka disini dapat dijelaskan istilah manajemen menurut George R. Terry manajemen adalah pencapaian tujuan yang ditetapkan terlebih dahulu dengan

51 Toni D. Widiastono, Pendidikan Manusia Indonesia, (Jakarta, PT. Kompas Media Nusantara, 2004), hal. 253.

52 Tony Bush dan Marianne Coleman, Fahrurrozi (terj.), Manajemen Mutu Kepemimpinan dan Kependidikan,(Jogjakarta: IRCiSoD, 2012) hal.191.

53 A. Malik Fadjar, School-Based Management, (Jakarta: Logos, 2002), hal. 16.

54 Jamal Ma'mur Asmani, Manajemen Pengelolaan Pendidikan dan Kepemimpinan Pendidikan Professional . (Yogyakarta: DIVA Press, 2009), hal. 70. 
mempergunakan kegiatan orang lain. Dengan konsepnya Planning, Organizing, Actuating, dan Controling. ${ }^{55}$

Secara luas, fungsi dan manajemen berlaku dalam bidang yang sangat luas atau dalam bidang-bidang umum seperti (perusahaan, organisasi, pemerintah), karena itu sifatnya yang universal. Dalam pandangan ajaran Islam, manajemen merupakan rangkaian segala sesuatu yang mengatur kegiatan tersebut berjalan sesuai dengan tujuannya dan segala sesuatu itu harus tertata secara rapi, benar, tertib dan teratur sebagaimana Sabda Rasulullah SAW yang diriwayatkan oleh Thabrani :

Artinya:Sesungguhnya Allah sangat mencintai orang yang jika melakukan suatu pekerjaanm dilakukan secara itqan (tepat, terarah, jelas, dan teratur). Melihat dari hadits tersebut bahwa segala sesuatu harus dilakukan dengan itqan yang penuh dengan tanggung jawab agar segala sesuatu yang kita kerjakandapat bermanfaat dan tercapai. Oleh karena itu, bilamana manajemen kaitkandengan rasa penuh tanggung jawab, pembagian kerja dan efisiensi. Maka haltersebut searah dengan makna Al-Qur'an sesuai dengan Firman Allah SWT. Dalam surat Al-Zalzalah ayat 7-8 Artinya:Barangsiapa yang mengerjakan kebaikan seberat dzarrahpun,niscaya Dia akanmelihat (balasan)nya. Dan Barangsiapa yang mengerjakan kejahatan sebesardzarrahpun, niscaya Dia akan melihat (balasan)nya pula. (Q.S. Al Zalzalah: 7-8). 56

Proses-proses manajemen pada dasarnya adalah perencanaan segala sesuatu yang mantap untuk melahirkan keyakinan yang berdampak pada melakukan sesuatu sesuai dengan aturan dan memiliki manfaat 4 . Oleh sebab itu,manajemen perlu melakukan rekonstruksi dalam meningkatkan kualitas dan mutu pendidikan.

Pendidikan pada dasarnya bertujuan untuk membantu individu mencapai perkembangan yang optimal sesuai dengan potensi yang dimilikinya, dan melalui pendidikan dapat diwujudkan generasi muda yang berkualitas baik dalam bidang akademisi, religious maupun moral. Hal ini erat kaitannya dengan Undang- Undang Nomor 20 Tahun 2003 Tentang Sistem Pendidikan Nasional dinyatakan bahwa pendidikan nasional bertujuan untuk memngembangkan potensi peserta didik menjadi manusia yang beriman dan bertakwa kepada tuhan Yang Maha Esa, berakhlak mulia, sehat, berilmu, cakap, kreatif, mandiri, dan menjadi warga Negara yang demokratis serta bertanggung jawab. ${ }^{57}$

Jika pendidikan anak jauh jauh dari akidah islam, terlepas dari arahan religious dan tidak berhubungan dengan Allah, maka tidak diragukan lagi

55 M. Manullang, Dasar-Dasar Manajemen. (Yogyakarta: Gajah Mada University Press, 2008), hal. 20.

56 Depag RI, Al-Qur'an dan Terjemahannya, 1971, hal. 1087.

57 Undang-Undang Nomor 20 Tahun 2003 Tentang Sistem Pendidikan Nasional. 
bahwa anak akan tumbuh diatas dasar kefasikan, penyimpangan, kesesatan dan kekafiran. Bahkan ia akan mengikuti hawa nafsu dan bergerak dengan contoh nafsu negatif dan bisikan-bisikan setan sesuai dengan tabiat, fisik, keinginan dan tuntutannya yang rendah. ${ }^{58}$

Maka dapat disimpulkan bahwa pendidikan merupakan suatu kebutuhan pokok setiap manusia dan mengembangan potensi yang dimilikinya. Karena dengan pendidikan manusia akan membawa kepada derajat kemanusiaan dan kemulyaan,seperti yang dijelaskan dalam firman Allah SWT dalam QS. Al- Mujadilah: 11

Artinya:"Hai orang-orang beriman apabila dikatakan kepadamu: "Berlapang- lapanglah dalam majlis", maka lapangkanlah niscaya Allah akan memberi kelapangan untukmu. Dan apabila dikatakan: "Berdirilah kamu", maka berdirilah, niscaya Allah akan meninggikan orang-orang yang beriman di antaramu dan orang-orang yang diberi ilmu pengetahuan beberapa derajat. Dan Allah Maha Mengetahui apa yang kamu kerjakan".59

Sejalan dengan tujuan pendidikan, pendidikan adalah pembentukan potensi kepribadian manusia, untuk itu pendidikan merupakan proses yang dilakukan melalui aktivitas secara terencana dalam mengarahkan segenap kemampuan dalam memberikan bimbingan dan latihan kepada anak didik agar memiliki kepribadian yang baik. Dengan demikian, keberadaan lembaga pendidikan diharapkan bermutu, yang dikelola secara optimal oleh tenaga pengajar yang professional merupakan suatu keharusan, karena lembaga pendidikan yang bermutu akan menghasilkan output yang berkualitas. Salah satu stakeholder yang berperan penting menentukan keberhasilan lembaga pendidikan yaitu kepala madrasah. Wahjosumidjo mengatakan bahwa " Beberapa di antara kepala sekolah dilukiskan sebagai orang yang memiliki harapan tinggi bagi para staf dan para siswa, kepala sekolah adalah mereka yang banyak mengetahui tugas-tugas mereka yang menentukan irama bagi sekolah mereka."60

Kepala sekolah merupakan salah satu komponen pendidikan yang paling berperan dalam meningkatkan kualitas pendidikan. Sebagaimana diungkapkan dalam pasal 12 ayat 1 PP 28 tahun 1990 bahwa: "kepala sekolah bertanggung jawab atas penyelenggaraan kegiatan pendidikan, administrasi sekolah, pembinaan tenaga kependidikan lainnya, dan pendayagunaan serta pemeliharaan sarana dan prasarana." 61

58 Abdullah Nashih, Ulwan. Pedoman Pendidikan Anak Dalam Islam, (Semarang, Asy- syifa, 2010), hal. 174.

59 Departemen Agama RI, Al-Qur'an dan Terjemahan, (Bogor, PT Sygma Examedia Arkanlema, 2007), hal,. 544.

${ }^{60}$ Wahjosumidjo, Kepemimpinan Kepala Sekolah, Tinjauan Teoritik dan Permasalahannya, (Jakarta. Raja Grafindo, 2004), hal. 83.

61E.Mulyasa, menjadi kepela sekolah profesional ,(Bandung :Remaja Rosdakarya,2009),hal.25. 
Berdasarkan uraian di atas, maka keberhasilan suatu lembaga pendidikan tergantung pada kepemimpinan kepala sekolah . maka kepala sekolah harus membawa lembaganya kearah tujuan yang telah ditetapkan. Peran kepala sekolah sebagai pemimpin institusi satuan pendidikan sangat penting. Kepala sekolah memiliki tugas dan fungsi yang sangat kompleks dalam pengelolaan sekolah, seperti sebagai manajer, pemimpin juga sebagai staf. Kepala sekolah merupakan motor penggerak penentu arah kebijakan sekolah.

Secara sederhana kepala sekolah dapat didefinisikan sebagai "seseorang tenaga fungsional guru yang diberi tugas untuk memimpin suatu sekolah di mana diselenggarakan proses belajar mengajar, atau tempat dimanan terjadi interaksi antara guru yang member pelajaran dan murid yang menerima pelajaran",62 kepala sekolah adalah penjabat formal, sebab pengangkatannya melalui suatu proses dan prosedur yang didasarkan pada peraturan yang beralaku. ${ }^{63}$

Dari definisi di atas, dapat disimpulkan bahwa seorang yang ditunjuk sebagai pemimpin pada satuan pendidikan merupakan pemimpin formal, sehingga secara organisatoris mempunyai tugas membina, membimbing seluruh warga, sekolah untuk mencapai tujuan pendidikan yang telah ditetapkan, dengan kesadaran tersebut para guru, staf, dan peserta didik dengan penuh semangat keyakinan melaksanakan tugas masing-masing untuk mencapai tujuan Sekolah.

Namun kenyataan dilapangan masih banyak kepala sekolah yang tidak menjalankan tugas dan fungsinya sebagai pemimpin pendidikan ini disebabkan karena dalam proses pengangkatannya tidak ada trasnfaransi, rendahnya mental kepala sekolah yang ditandai dengan kurangnya motivasi dan semangat serta kurangnya disiplin dalam melakukan tugas, dan seringnya datang terlambat serta banyak faktor penghambat lainnya untuk meningkatkan kualitas pendidikan yang mengimplikasikan rendahnya produktivitas kerja kepala sekolah yang berimplikasi juga pada mutu (input, proses, dan output).

Seiring dengan tantangan kehidupan global, pendidikan merupakan hal yang sangat penting karena pendidikan salah satu penentu mutu Sumber Daya Manusia. Dimana dewasa ini keunggulan suatu bangsa tidak lagi ditandai dengan melimpahnya kekayaan alam, melainkan pada keunggulan Sumber Daya Manusia (SDM). Dimana mutu Sember Daya Manusia (SDM) berhubungan erat dengan mutu pendidikan, mutu pendidikan sering di indikasikan dengan kondisi yang baik, memenuhi syarat, dan segala komponen yang harus terdapat dalam pendidikan, komponen-komponen tersebut adalah masukan, proses, keluaran, tenaga kependidikan, sarana dan prasarana serta biaya.

\footnotetext{
62 Ibid, hal. 83.

$63 \mathrm{Ibid}$, hal. 85.
} 
Ketercapaian tujuan pendidikan sangat bergantung pada kecakapan dan kebijaksanaan kepemimpinan kepala sekolah yang merupakan salah satu pemimpin pendidikan. Karena kepala sekolah merupakan seorang pejabat yang profesional dalam organisasi sekolah yang bertugas mengatur semua sumber organisasi dan bekerjasama dengan guru-guru dalam mendidik siswa untuk mencapai tujuan pendidikan. Dengan keprofesionalan kepala sekolah ini pengembangan profesionalisme tenaga kependidikan mudah dilakukan karena sesuai dengan fungsinya, kepala sekolah memahami kebutuhan sekolah yang ia pimpin sehingga kompetensi guru tidak hanya pada kompetensi yang ia miliki sebelumnya, melainkan bertambah dan berkembang dengan baik sehingga profesionalisme guru akan terwujud.

\section{Metode Penelitian}

Penelitian ini menggunakan pendekatan kualitatif dalam bentuk metode deskriptif. Penggunaan deskriptif dalam penelitian ini untuk menggambarkan obyek penelitian atau kondisi lapangan apa adanya pada saat itu, untuk mengkaji permasalahan pada saat penelitian ini dilakukan. Penelitian ini berusaha mendeskripsikan dan menginterpretasikan apa adanya.

Penelitian ini menggunakan pendekatan kualitatif, diharapkan terangkat gambaran mengenai kualitas, realitas sosial dan persepsi sasaran penelitian tanpa tercemar oleh pengukuran formal. Penelitian didasarkan pada persepsi emik. Persepsi emik bertujuan untuk mengungkapkan dan mengurangi sistem dan perilaku bersama satuan strukturnya dan kelompok struktur satuan-satuan itu.

Sumber data dalam penelitian ini adalah Kepala Sekolah, Komite Sekolah, Tenaga Pendidik, Tenaga Kependidikan, Siswa dan Siswi SMK Darul Maghfiroh di Sinar Rejeki, Kecamatan Jati Agung, Kabupaten Lampung Selatan serta dokumen-dokumen yang berkaitan dengan permasalahan penelitian ini. Metode pengumpulan data dengan menggunakan observasi, wawancara, dan dokumentasi sedangkan analisis data dengan menggunakan data Reduction (reduksi data), Display (penyajian data), dan Verivikasi, (menarik kesimpilan).

\section{Pembahasan}

\section{Pengertian Kepala Sekolah}

Secara etimologi kepala sekolah adalah guru yang memimpin sekolah. ${ }^{64}$ Kepala sekolah dapat diartikan ketua atau pimpinan dalam suatu organisasi atau sebuah lembaga. Sedangkan sekolah sebuah lembaga dimana menjadi tempat menerima dan memberi pelajaran.

64 W.J.S. Poerwadarminto, Kamus Umum Bahasa Indonesia, (Jakarta: Balai Pustaka, 1976), hal. 482. 
Dengan demikian secara sederhana kepala sekolah dapat didefinisikan "guru yang diberi tugas untuk memimpin suatu sekola dimana diselenggarakan proses belajar mengajar, atau tmpaat dimana terjadi interaksi antara guru yang diberi pelajaran dan murid yang menerima pelajaran."65

2. Peran kepala sekolah

Menurut Bush. Peran kepala sekolah sebagai pendidik adalah membentuk budaya pengajaran dan pembelajaran kondusif. Kepala sekolah melakukan pembinaan mental dengan membina tenaga kependidikan tentang hal-hal yang berkaitan dengan sikap batin dan watak.

Peran kepala sekolah sebagai manajer pendidikan menurut Wuradji adalah (1) menyusun perencanaan secara matang tentang tujuan dan strategi pencapaian tujuan, (2) melakukan pengorganisasian potensi sumber-sumber pendidikan yang ada, (3) melaksanaan kegiatan, (4) mengadakan control secara rutin terhadap pelaksanaan dan hasil pendidikan. ${ }^{66}$

Secara umum, dalam tugas manajemen terlibat peran pokok yang ditampilkan oleh seorang pemimpin, yaitui: perencanaan (planning), pengorganisasian (organizing), dan pengawasan (controlling). Untuk melaksanaka peran poko tersebut seorang pemimpin harus mampu menjadi tauladan yang baik bagi orang-orang yang dipimpinnya. ${ }^{67}$

3. Pengertian Manajemen

Manajemen berasal dari bahasa latin yaitu asal kata dari Manus yang berarti tangan dan Agere yang berarti melakukan. Kata-kata itu digabungkan menjadi satu yaitu Manager yang mempunyai arti menangani. Kemudian diterjemahkan kedalam bahasa inggris manajement yang mempunyai arti dalam bahasa Indonesia manajemen atau pengelolaan. ${ }^{68}$

Pembahasan manajemen berkaitan dengan proses perencanaan, pengorganisasian, kepemimpinan, dan pengendalian, yang didalamnya

65 Wahdjosumijo, Kepemimpinan Kepala Sekolah, (Jakarta: PT Raja Grafindo Persada, 2007), hal. 83.

${ }^{66}$ Arif Jamali, Lantip Diat Prasojo SMA Muhammadiyah 3 Yogyakarta, Pascasarjana Universitas Negeri Yogyakarta Jurnal Akutabilitas Manajemen Pendidikan Volume 1, Nomor 1, 2014.

67Sobri Sutikno, ManajemenPendidikan, Langkah praktis Mewujudkan Lembaga Pendidikan yang Unggul, (Lombok, Holistica, 2012), hal. 123.

${ }^{68}$ Husaini Usman, Manaejemen Teori Praktek dan Riset Pendidikan. (Jakarta Timr: PT. Bumi Aksara, 2008), hal. 4. 
terdapat upaya dari anggota organisasi untuk mencapai tujuan yang telah ditetapkan bersama. ${ }^{69}$

4. Pengertian Mutu

Pengertian mutu dapat dilihat dari duasisi, yaitu segi normatif dan segi deskriptif. Dalam arti normatif, mutu ditentukan berdasarkan pertimbangan instrinsik dan ekstrinsik. Berdasarkan kriteria intrinsik, mutu pendidikan merupakan produk pendidikan yakni manusia yang terdidiksesuai standar ideal. Sedangkan berdasarkan kriteria ekstrinsik, pendidikan merupakan instrumen untuk mendidik tenaga kerja yang terlatih. Adapun dalam arti deksriptif, mutu ditentukan berdasarkan keadaan senyatanya misalnya hasil tes prestasi belajar.

Dengan demikian, mutu pendidikan adalah derajat keunggulan dalam pengelolaan pendidikan secara efektif dan efisien untuk melahirkan keunggulan akademis dan ekstra kurikuler pada peserta didik yang dinyatakan lulus untuk satu jenjang pendidikan atau menyelesaikan pembelajaran tertentu. ${ }^{70}$

5. Implementasi Manajemen Mutu Peserta Didik

Pada saat ini diperlukan adanya dukungan manajemen yang efektif dan efesien dalam organisasi pendidikan, karena semakin besarnya perhatian dan pengakuan dari berbagai pihak. Peserta didik perlu dibangun mentalitasnya sehingga mampu berpikir kreatif dan mampu mengembangkan minat serta bakatnya untuk mampu bersaing didunia kerja dan bias bekerja secara professional dan berdedikasi yang tinggi terhadap profesinya. Manajemen merupakan proses pendayagunaan semua sumber daya dalam rangka mencapai sebuah tujuan yang ditetapkan. Pendayagunaan yang melalui proses perencanaan, pengorganisasian, pengarahan, dan pengawasan disebut manajemen. ${ }^{71}$

6. Pengertian Peserta Didik

Pengertian peserta didik menurut undang-undang RI No. 20 tahun 2003 tentang system pendidikan Nasional adalah anggota masyrakat yang berusaha mengembangkan potensi diri melalui proses pembelajaran yang tertsedia pada jalur, jenjang, dan jenis pendidikan tertentu. Peserta didik adalah orang yang mempunyai pilihan untuk menempuh ilmu sesuai dengan cita-cita dan harapan masa depan. Oemar Hamalik, mendefinisikan peserta didik sebagai suatu komponen masukan dalam system pendidikan, yang selanjurtnya diproses dalam

${ }^{69}$ Hikmat, Manajemen Pendidikan, (Bandung, Pustaka Setia, 2009) hal. 11.

70Marsus Suti, Strategi Peningkatan Mutu di Era Otonomi PendidikanJurnal MEDTEK, Volume 3, Nomor 2, Oktober 2011.

71Ibrahim Bafadal, Manajemen Perlengkapan Sekolah dan Aplikasinya, (Jakarta, PT Bumi Aksara, 2004), hal. 1. 
proses pendidikan, sehingga menjadi manusia yang berkualitas sesuai dengan tujuan pendidikan nasional.

Peserta didik salah satu komponen pendidikan, disamping komponen lainnya seperti guru, tujuan, materi pelajaran dan komponen lainnya. Guru yang mampu memahami keberadaan murid secara cermat berdasarkan berbagai tinjauan; psikologi, filsafat, sosiologi, budaya, adalah guru yang efektif guru yang mampu mengenal murid akan lebih mudah menyusun rencana atau program pengajaran. Bagaimanapun diantara sejumlah murid memiliki karakteristiknya dan sikap tersendiri berbeda dengan murid yang lain. Guru dituntut untuk professional dalam menangani keberagaman seperti ini. Peserta didik adalah makhluk individu, yang memiliki kepribadian dengan cirri-ciri yang khas sesuai dengan perkembangan dan pertumbuhannya. Perkembangan dan pertumbuhan peserta didik mempengaruhi sikap dan tingkah lakunya. Sementara perkembangan dan pertumbuhan peserta didik dipengaruhi oleh lingkungan ia berada. (Shaleh Abdul Aziz). ${ }^{72}$

7. Peran Kepala Sekolah dalam Implementasi Manajemen Mutu Peserta Didik

Dalam Kamus Besar Bahasa Indonesia kata peran artinya "perangkat tingkah laku yang diharapkan dimiliki oleh orang yang berkedudukan di masyarakat". Berdasarkan arti kata tersebut dapat penulis jelaskan bahwa "peran" adalah bagian dari tugas yang dibebankan kepada seseorang. Peran Kepala Madrasah adalah sebagai aktualisasi kongkrit dari fungsi, administrasi, supervisi, dan evaluasi. Salah satu peranan yang dapat dilakukan melalui optimalisasi peran kepala madrasah. Idochi Anwar Dan Yayat Hidayat Amir mengemukakan bahwa "kepala sekolah sebagai pengelola memiliki tugas mengembangkan kinerja personel, terutama meningkatkan kompetensi professional guru".

Dengan demikian berarti bahwa untuk dapat melaksanakan suatu rencana atau program sehingga mencapai hasil yang baik, maka diperlukan adanya organisasi dan koordinasi yang baik dan teratur, adanya komunikasi yang jelas dan lancar, adanya pengawasan atau supervisi yang berkesinambungan serta konsekuen, serta adanya penilaian atau evaluasi yang dilakukan dengan teratur dan tepat. Untuk setiap akhir suatu kegiatan diadakan evaluasi untuk menilai rencana yang mana yang telah berhasil, dan program yang mana yang belum dapat berjalan dengan lancar.

Penelitian tentang peran kepala sekolah sangat penting bagi guru-guru dan murid-murid. Pada umunya kepala sekolah memiliki

72 Ramayulis, Dasar-Dasar Kependidikan Suatu Pengantar Ilmu Pendidikan, (Jakarta, Kalam Mulia, 2013) hal. 159. 
tanggung jawab sebagai pemimpin di bidang pengajaran, pengembangan kurikulum, administrasi kesiswaan, administrasi personalia staf, hubungan masyarakat, dan perlengkapan serta organisasi sekolah. Dalam memberdayaan masyarakat dan lingkungan sekitar, kepala sekolah merupakan kunci keberhasilan yang harus menaruh perhatian tentang apa yang terjadi pada peserta didik di sekolah dan apa yang dipikirkan orang tua dan masyarakat tentang sekolah. Cara kerja kepala sekolah dan cara ia memandang peranannya dipengaruhi oleh kepribadiannya, persiapan dan pengalaman profesionalnya, serta ketetapan yang dibuat oleh sekolah mengenai peranan kepala sekolah di bidang pengajaran. Pelayanan pendidikan dalam dinas bagi administrator sekolah dapat memperjelas harapanharapan atas peranan kepala sekolah.

Berdasarkan tugasnya peran kepala sekolah yaitu: Kepala sekolah berperan sebagai pemimpin, menyusun perencanaan, mengorganisasikan kegiatan, mengarahkan kegiatan, mengkoordinasikan kegiatan, melaksanakan pengawasan, melakukan evaluasi terhadap kegiatan, menentukan kebijaksanaan, mengadakan rapat, mengambil keputusan, mengatur proses belajar mengajar, mengatur administrasi, mengatur OSIS, mengatur hubungan sekolah dengan masyarakat dan instansi terkait.

Menurut Purwanto, bahwa seorang kepala sekolah mempunyai sepuluh macam peranan, yaitu: "Sebagai pelaksana, perencana, seorang ahli, mengawasi hubungan antara anggota -anggota, mewakili kelompok dalam tindakannya ke luar, bertindak sebagai pemberi ganjaran, bertindak sebagai wasit, pemegang tanggung jawab, sebagai seorang pencipta, dan sebagai seorang ayah".

Peran Kepala Sekolah Sebagai Pemimpin (Leader), Dalam teori kepemimpinan setidaknya kita mengenal dua gaya kepemimpinan yaitu kepemimpinan yang berorientasi pada tugas dan kepemimpinan yang berorientasi pada manusia. Dalam rangka meningkatkan kompetensi guru, seorang kepala sekolah dapat menerapkan kedau gaya kepemimpinan tersebut secara tepat dan fleksibel, disesuaikan dengan kondisi dan kebutuhan yang ada. Mulyasa menyebutkan kepemimpinan seseorang sangat berkaitan dengan kepribadian, dan kepribadian kepala sekolah sebagai pemimpin akan tercemin sifat - sifat sebagai berikut : (1) jujur; (2) percaya diri; (3) tanggung jawab; (4) berani mengambil resiko dan keputusan; (5) berjiwa besar; (6) emosi yang stabil; dan (7) teladan.

Dengan tercapainya syarat-syarat tersebut sebagai pemimpin, diharapkan dapat tercipta pelaksanaan tugas yang baik dalam mencapai tujuan pendidikan di sekolah yang dipimpinnya dan dapat menunjang tujuan pendidikan nasional pada umumnya. Sebagaimana yang dikemukakan oleh Ngalim Purwanto bahwa syarat-syarat sebagai kepala sekolah di antaranya : "memiliki ijazah yang sesuai dengan 
peraturan yang telah ditetapkan oleh pemerintah, mempunyai pengalaman kerja yang cukup, memiliki kepribadian yang baik, mempunyai keahlian dan berpengetahuan luas, mempunyai ide dan inisiatif yang baik untuk kemajuan dan pengembangan madrasah.

\section{Hasil Penelitian}

Dalam tugas manajemen terlibat peran pokok yang ditampilkan oleh seorang pemimpin, yaitu: perencanaan (planning), pengorganisasian (organizing), dan pengawasan (controlling). Untuk melaksanakan peran pokok tersebut seorang pemimpin harus mampu menjadi tauladan yang baik bagi orang-orang yang dipimpinnya. Kepala sekolah memiliki sepuluh peran yang harus dilaksanakan ketika hendak memimpin lembaga pendidikan, akan tetapi penulisi hanya akan menjabarkan dua peran pokok kepala sekolah yang menurut penulis sangat penting, yaitu

1. Sebagai Pelaksana (Executifl), Seorang pemimpin ketika hendak akan dilaksanakannya ajaran baru pada awal semester harus mengadakan musyawarah dengan dewan guru dan staf untuk merncanakan kegiatan belajar mengajar sesuai dengan kurikulum yang berlaku. Karena dalam pelaksanaan pembelajaran tidak bisa dilaksanakan sembarangan tanpa ada aturan yang berlaku.

2. Menjaga Hubungan dengan Kelompok (controller of internal relationship) Menjaga suatu hubungan yang ada diinternal sekolah sangatlah penting demi menjaga keharmonisan dan keserasian kelompok atau anggota, karena dalam mencapai tujuan pendidikan yang baik, perselisihan antara pemimpin dangan anggota, anggota dengan anggota harus di hindari karena sangat merugikan lembaga itu sendiri dan berakibat tidak tercapainya tujuan pendidikan.

Penelitian tentang peranan kepala sekolah sangat penting bagi guruguru dan murid-murid. Pada umumnya kepala sekolah memiliki tanggung jawab sebagai pemimpin di bidang pengajaran, pengembangan kurikulum, administrasi kesiswaan, administrasi personalia staf, hubungan masyarakat, administrasi school plant, dan perlengkapan serta organisasi sekolah. Dalam memberdayakan masyarakat dan lingkungan sekitar, kepala sekolah merupakan kunci keberhasilan yang harus menaruh perhatian tentang apa yang terjadi pada peserta didik di sekolah dan apa yang dipikirkan orang tua dan masyarakat tentang sekolah. Cara kerja kepala sekolah dan cara ia memandang peranannya dipengaruhi oleh kepribadiannya, persiapan dan pengalaman profesionalnya, serta ketetapan yang dibuat oleh sekolah mengenai peranan kepala sekolah di bidang pengajaran. Pelayanan pendidikan dalam dinas bagi administrator sekolah dapat memperjelas harapan-harapan atas peranan kepala sekolah. Peran kepala sekolah pada abad 21 sebagai berikut.

1. Berpartisipasi pada pembelajaran sebanyak $91 \%$.

2. Mengarahkan para guru untuk menentukan pembelajaran dengan 
menggunakan evaluasi formatif sebanyak $90 \%$.

3. Perencanaan, koordinasi dan evaluasi pengajaran, kurikulum dan padegogi (terlibat langsung dengan mengunjungi kelas secara regular, dan memberikan feedback pada pembelajaran) sebanyak $74 \%$.

4. Memastikan para guru mendaat informasi tentang praktik pembelajaran yang terbaru sebanyak $64 \%$.

5. Pengelolaan suber daya sebanyak $60 \%$.

6. Menentukan status quo sebanyak $60 \%$.

7. Menentukan tujuan dan harapan sebanyak $54 \%$

8. Menjaga lingkungan yang mendukung pembelajaran sebanyak $49 \%$.

Berdasarkan hasil penelitian tersebut, peran kepala sekolah paling banyak berkaitan dengan pembelajaran. Hal ini menujukan bahwa kepala sekolah sangat berperan dalam peningkatan mutu pendidikan di sekolah. Kepala sekolah juga harus paham tentang pembelajaran, mulai dari merencanakan, melaksanakan, sampai pada evaluasi sebagai bahan pembinaan guru dlam menngkatkan kinerjanya. Jadi, dalam konteks ini kepala sekolah tidak hanya paham cara mengelola sekolah, sesuai dengan perannya sebagai manajer, tetapi harus paham tentang berbagai hal yang berkaitan dengan pembelajaran.

Dalam implementasi manajemen mutu peserta didik di SMK Darul Maghfiroh Sinar Rejeki Jati Agung Lampung Selatan kepala sekolah harus dapat memberikan pengaruh yang baik kepada guru agar mereka menjalankan tugasnya dengan sepenuh hati. Sebagai seorang pemimpin diharapkan oleh bawahannya dalam memimpin organisi di sekolah para pemimpinnya memberikan arahan yang tepat untuk keterpencapaian tujuan sekolah tersebut.

Peran kepala sekolah dalam implementasi manajemen yaitu menyusun perencanaan, mengorganisasikan kegiatan, mengarahkan kegiatan, mengkoordinasikan kegiatan, melaksanakan pengawasan, melakukan evaluasi terhadap kegiatan, menentukan kebijaksanaan, mengadakan rapat, mengambil keputusan, mengatur proses belajar mengajar, mengatur administrasi, mengatur OSIS, mengatur hubungan sekolah dengan masyarakat dan instasi lain.

Pada dasarnya peran kepala sekolah dalam implementasi manajemen mutu peserta didik tidak bisa dipisahkan dari cara kepemimpinannya yang sangat berpengaruh terhadap kedisiplinan para guru dan murid. Dalam penerapan kepemimpinan hendaklah seorang pemimpin dapat menunjukkan sebagai seorang pemimpin dan dapat memotivasi para guru dan peserta duidik dalam rangka meningkatkan kedisiplinan kerja, belajar mengajar, bimbingan, motivasi, pengawasan serta petunjuk dari kepala sekolah.

Dalam menjalankan perannya kepala sekolah tidak dapat menjalankan tugasnya dengan sednirian, akan tetapi kepala sekolah harus mampu mengajak semua staf yang terlibat untuk mewujudkan tujuan 
pendidikan tersebut, dan kepala sekolah dituntut untuk tidak bersifat semena-mena atau otoriter dalam mempimpin anggota kelompoknya. Kepemimpinan yang efektif dapat tercipta apabila kepala sekolah memiliki sifat, perilaku dan keterampilan yang baik untuk memimpin sebuah organisasi sekolah. Dalam perannya sebagai pemimpin, kepala sekolah harus mampu untuk mempengaruhi semua orang yang terlibat dalam proses pendidikan yaitu guru dan pesetta didik untuk menciptakan iklim sekolah yang positif untuk mencapai tujuan dan kualitas sekolah

Acuan yang dijadikan sebagai indikator kepala sekolah melakukan peranannya dalam implementasi manajemen berjalan dengan lancar antara lain:

1. Memberikan contoh teladan yang baik bagi guru dan peserta didik

2 Kunjungan kelas untuk mengawasi proses pelaksanaan pembelajaran

3. Meneliti dan mengecek perangkat perangkat pendukung pembelajaran

4 Mengawasi penggunaan waktu kegiatan beljar mengajar.

5. Menegur dan mengingatkan guru yang kurang disiplin

6. Mengadakan evaluasi program sekolah dan kinerja guru

Dari indikator yang telah penulis siapkan ketika pelaksanaan wawancara, maka akan penulis jelaskan hasil dari wawancara pada hari senin tanggal 10 September 2018 jam 9:30, bersama Bapak Kodirin SPd.I sebagai berikut :73

Hasil wawancara dengan kepala sekolah bapak Kodirin SPd.I beliau menjelaskan apa yang saya tanyakan ketika wawancara beliau menjawab apa yang saya tayakan seperti, Apakah kepala sekolah memberikan instruksi yang jelas ketika memberikan tugas kepada anggotanya ? Jawaban kepala sekolah : iya, pastinya saya harus dapat memberikan instruksi yang jelas guna menghindari kesalahpahaman antara kepala sekolah dan guru dan dapat dipertanggungngjawabkan.

Hasil wawancara dengan kepala sekolah bapak Kodirin SPd.I beliau menjelaskan apa yang saya tanyakan ketika wawancara beliau menjawab apa yang saya tayakan seperti, apakah kepala sekolah mampu mengevaluasi kegiatan belajar mengajar yang telah dilaksanakan? Jawaban kepala sekolah : saya selaku kepala sekolah di SMK Darul Maghfiroh harus dapat melaksanakan tugas saya dengan baik guna meningkatkan kualitas yang ada disekolah ini, hal-hal yang telah dilaksanakan maka harus saya evaluasi apakah sudah berjalan dengan baik ataupun belum, hal ini perlu saya lakukan agar kegiatan yang telah direncanakan tepat sasaran dan dapat meningkatkan mutu pendidikan di sekolah ini.

Hasil wawancara dengan kepala sekolah bapak Kodirin SPd.I belia menjelaskan apa yang saya tanyakan ketika wawancara beliau menjawab

73Kodirin SPd.I, wawancara di SMK Darul Maghfiroh pada hari senin jam 9:30 WIB tanggal 10 September 2018. 
apa yang saya tayakan seperti, bagaimana kepala sekolah dalam memberikan penilaian terhadap anggotanya apakah secara obyektif ? jawaban kepala sekolah : saya selaku kepala sekolah haruslah adil dalam memberikan penilaian kepda para anggota saya, hal ini perlu saya lakukan guna menghindari kecemburuan sosial yang berakibat rusaknya sebuah hubungan

Hasil wawancara dengan kepala sekolah bapak Kodirin SPd.I beliau menjelaskan apa yang saya tanyakan ketika wawancara beliau menjawab apa yang saya tayakan seperti, bagaimana tindakan kepala sekolah ketika hendak akan melaksanakan kegiatan di sekolah? jawaban kepala sekolah : ketika akan merencanakan kegiatan yang berkaitan dengan sekolah ini, saya tentu tidak bisa melaksanakan sendiri, maka diperlukan suatu musyawarah bersama dewan guru dan staf, hal ini perlu dilakukan agar tidak terjadi kesenjangan dan kesalahpahaman.

Hasil wawancara dengan kepala sekolah bapak Kodirin SPd.I beliau menjelaskan apa yang saya tanyakan ketika wawancara beliau menjawab apa yang saya tayakan seperti, bagaimanakah kepala sekolah dalam memberikan dukungan kegiatan yang berkaitan tentang peningkatan kompetensi guru? jawaban kepala sekolah : dalam meningkatkan kompetensi guru yang harus dilaksanakan yaitu dengan mengadakan pelatihan dan seminar yang menunjang kinerja guru dan dituntut agar guru dapat menjalankan tugasanya dengan profesional.

Hasil wawancara dengan kepala sekolah bapak Kodirin SPd.I beliau menjelaskan apa yang saya tanyakan ketika wawancara beliau menjawab apa yang saya tayakan seperti, bagaimana kepala sekolah dalam memberikan motivasi kepada guru dan peserta didik serta memberikan inovasi dalam pembelajaran ? jawaban kepala sekolah : Saya selaku kepala sekolah harus lah mendukung semua kegiatan belajar mengajar dan yang lainnya yang berkaitan dengan pembelajaran dengan beberapa kali mendampingi ataupun berkunjung disetiap kelas, serta memberikan hadiah bagi peserta didik yang mendapatkan prestasi setiap satu semester dan juga memeberikan penghargaan dan dukungan bagi peserta didik yang mengikuti lomba Serta memfasilitasi nya.

Hasil wawancara dengan kepala sekolah bapak Kodirin SPd.I beliau menjelaskan apa yang saya tanyakan ketika wawancara beliau menjawab apa yang saya tayakan seperti, bagaimana kepala sekolah memberikan rasa nyaman kepada guru dan peserta didik ? jawaban kepala sekolah : untuk memberikan rasa nyaman, maka saya harus menjaga komunikasi dengan guru dan siswa dengan baik, dan tidak bersikap terlalu otoriter atau bertindak semau saya tanpa mempertimbangkan beberapa aspek.

Hasil wawancara dengan kepala sekolah bapak Kodirin SPd.I beliau menjelaskan apa yang saya tanyakan ketika wawancara beliau menjawab apa yang saya tayakan seperti, bagaimanakah kepala sekolah memberikan contoh teladan yang baik kepada guru dan peserta didik? jawaban kepala 
sekolah : saya tidak memerintahkan mereka untuk selalu berbuat baik akan tetapi saya diam diruangan saya, yang saya inginkan maka saya juga harus siap untuk melaksanakan juga dalam keseharian saya, karena memberikan nasehat akan lebih gampang ketika kita juga dapat meberikan contoh, tidak hanya dari perkataan saja.

\section{Kesimpulan}

Dari hasil penelitian tentang Peran Kepala sekolah dalam Implementasi Manajemen Mutu Peserta Didik di SMK Darul Maghfiroh Sinar Rejekei Jati Agung Lampung Selatan. Baik melalui wawancara, observasi, dokumentasi maka dengan demikian penulis simpulkan.

Peran kepala sekolah dalam implementasi manajemen mutu dengan melaksanakan tugasnya dengan tepat yaitu menyusun perencanaan, mengorganisasikan kegiatan, mengarahkan kegiatan, melaksanakan pengawasan, serta melaksanakan pengelolaan manajemen dan mengatur hubungan sekolah dengan masyarakat dan instasi lain. Kepala sekolah adalah pemegang kendali di sekolahnya sehingga dalam mengatur dan melaksanakan itu semua kepala sekolah tidak bisa melakukannya sendiri, kepala sekolah harus dapat mengajak dan memberikan pengaruh yang positif agar guru dan peserta didik dapat bekerja sama dengan sepenuh hati, dengan seperti itu maka tujuan sekolah akan lebih mudah tercapai.

Kepala sekolah adalah pemegang kendali di sekolahnya sehingga dalam mengatur dan melaksanakan itu semua kepala sekolah tidak bisa melakukannya sendiri, kepala sekolah harus dapat mengajak dan memberikan pengaruh yang positif agar guru dan peserta didik dapat bekerja sama dengan sepenuh hati, dengan seperti itu maka tujuan sekolah akan lebih mudah tercapai.

\section{Daftar Pustaka}

A. Malik Fadjar, School-Based Management, Jakarta: Logos. 2002.

Abdullah Nashih, Ulwan. Pedoman Pendidikan Anak Dalam Islam, Semarang, Asy- syifa, 2010.

Amirudin, Kepemimpinan Kepala Madrasah Dalam Meningkatkan Kedisiplinan Guru, Fakultas Tarbiyah dan Keguruan UIN Raden Intan Lampung , Al-Idarah: Jurnal Kependidikan Islam Vol. 7 No. 2, Desember 2017.

Arif Jamali, Lantip Diat Prasojo SMA Muhammadiyah 3 Yogyakarta, Pascasarjana Universitas Negeri Yogyakarta. Jurnal Akutabilitas Manajemen Pendidikan Volume 1, Nomor 1, 2014.

Depag RI, Al-Qur'an dan Terjemahannya, 1971.

Departemen Agama RI, Al-Qur'an dan Terjemahan, Bogor, PT Sygma Examedia Arkanlema. 2007.

E.Mulyasa, menjadi kepela sekolah profesional,Bandung :Remaja Rosdakarya. 2009. 
Hikmat, Manajemen Pendidikan. Bandung, Pustaka Setia. 2009.

Husaini Usman, Manaejemen Teori Praktek dan Riset Pendidikan. Jakarta Timr: PT. Bumi Aksara, 2008.

Ibrahim Bafadal, Manajemen Perlengkapan Sekolah dan Aplikasinya, Jakarta, PT Bumi Aksara. 2004.

Jamal Ma'mur Asmani, Manajemen Pengelolaan Pendidikan dan Kepemimpinan Pendidikan Professional . Yogyakarta: DIVA Press. 2009.

M. Manullang, Dasar-Dasar Manajemen. Yogyakarta: Gajah Mada University Press. 2008.

Marsus Suti, Strategi Peningkatan Mutu di Era Otonomi PendidikanJurnal MEDTEK, Volume 3. Nomor 2. Oktober 2011.

Nasution, Teknologi Pendidikan. Jakarta. Bumi Aksara. 1990.

Ramayulis, Dasar-Dasar Kependidikan Suatu Pengantar Ilmu Pendidikan, Jakarta, Kalam Mulia, 2013.

Sobri Sutikno, ManajemenPendidikan, Langkah praktis Mewujudkan Lembaga Pendidikan yang Unggul. Lombo., Holistica. 2012.

Toni D. Widiastono, Pendidikan Manusia Indonesia. Jakarta. PT. Kompas Media Nusantara. 2004.

Tony Bush dan Marianne Coleman, Fahrurrozi (terj.), Manajemen Mutu Kepemimpinan dan Kependidikan, Jogjakarta: IRCiSoD. 2012.

Undang-Undang Nomor 20 Tahun 2003 Tentang Sistem Pendidikan Nasional.

W.J.S. Poerwadarminto. Kamus Umum Bahasa Indonesia. Jakarta: Balai Pustaka. 1976.

Wahdjosumijo. Kepemimpinan Kepala Sekolah, Jakarta: PT Raja Grafindo Persada. 2007.

Wahjosumidjo. Kepemimpinan Kepala Sekolah, Tinjauan Teoritik dan Permasalahannya. Jakarta. Raja Grafindo. 2004. 